\title{
Receiving and Rendering Notes on the Edited Shakespeare Page
}

\author{
Paul J. Hecht
}

\begin{abstract}
This essay argues for a greater variety of approaches to editing Shakespeare, including editors who may creatively and productively refashion or distort the text, not just clarify it. Following an aggressive, seemingly spurious emendation to a speech in As You Like It by eighteenth-century editor William Warburton (here called a "dead crux"), the author explores how the dynamics of a Shakespeare scene inflect and infect the voice of the editor, in a way all but unimaginable within the predominant, professional tone of present-day Shakespeare editing. Working from the speculative writing of Lawrence Lipking, and the editorial provocations of James Joyce, as well as Shakespeare himself, other possibilities for the relationship of text, editor, edition, and reader are considered; this in the context of a reading, based on Warburton's emendation, of the Shakespeare scene in question.
\end{abstract}

$\mathrm{T}$ he CONtingency of the editorial tradition of ShakeSPEARE, the way influential individuals and ideas shaped how many subsequent editors approached the text, has been visible for a long time. ${ }^{1}$ Since the 1990s, however, the sense of contingency has been considerably deepened. Margreta de Grazia's Shakespeare Verbatim (1991) displayed the social and political influences woven into Malone's edition of 1790, and demonstrated just how spurious was the view of editorial progress whereby one saw, in "the history of Shakespeare studies one streamlined course whose

This essay has had a long gestation, and has accrued many debts, though responsibility for the flaws of the final product remain all mine. I wish to thank Timothy Billings, Marshall Brown, Peter Holland, Richard Strier, Suzanne Gossett, Matthew Harrison, H. Wayne Storey, and Daniel O'Sullivan, as well as two anonymous readers, for their insights and thoughtful recommendations, which have improved the essay immeasurably.

1. Faced with the complexity of the textual situation for many plays, editors have been particularly susceptible to theoretical interpretations that order the materials in various ways. For the most comprehensive, recent overview, see MurРHY 2003. 
most advanced point was always the present" (7). ${ }^{2}$ In 1996, Leah Marcus argued for how editors should respond to this newly clarifying understanding of editorial history in Unediting the Renaissance - a phrase that has stuck. Marcus accepted the claims of de Grazia and others, that "our standard editions are shaped by nineteenth-century or even earlier assumptions and ideologies", and advocated looking at unedited, original texts in order to get free of "centuries of editorial accretion", a metaphorical weight that can cause even avowedly experimental editions to "collapse into received orthodoxy" (5).

In more recent work Marcus has continued to argue for "breaking the authority of past editorial practice in favor of greater openness and multiplicity" (Marcus 2007, 142). In the prior decade much had happened, both in terms of heightened consciousness among editors of the weight of the editorial past, and also in the way texts are presented, including "parallel text" editions that avoid conflation and an array of new web-based approaches to presenting and reading Shakespeare. But Marcus insisted that more remained to be done. Despite the continuing flow of new editions of Shakespeare, they remained, she claimed, "too uniform, too much alike, too often geared to the same audience rather than to disparate audiences" (142). The point about audiences seems crucial. It is not that Marcus thinks all Shakespeare editing, all taking away of possibility (variety, for example, of word or phrase in multiple play-texts) and inserting of clarifying gloss and explanation, is bad. ${ }^{3}$ Far from it. It is rather that there is too much uniformity in what I would call the editorial voice, upon the stage, as it were, of the critical edition, in which glosses dispassionately explain and illuminate. Whereas, if one goes sufficiently far into the past of Shake-

2. More recently, in Shakespeare and Renaissance Literature before Heterosexuality (2007), Rebecca Ann Bach argued that in the evolution of Shakespeare editing one can see the gradual emergence of modern notions of gender roles and the place of sexual desire that would have been utterly alien to Elizabethans. Editors, she argues, have unconsciously emphasized and deemphasized aspects of the text to fit the governing cultural view of men and women.

3. I quote Marcus at length in part to counter an argument put forward by Lukas Erne that Marcus and those of like mind are against editing in general, that they suggest that the only tolerable edition of a Renaissance text is a photofacsimile. It seems clear that both in 1996 and 2007, Marcus has supported a greater multiplicity of editorial approaches, pushing commentary along a continuum away from "dogmatism" and ignorant acceptance of past editors' choices. See ERNE 2008, 4-6, 9-10. Note that most of Erne's support for the notion of "abandonment" of editing comes from essays written in the 1980s. 
speare editing, one finds true multiplicity of voice, the present has instead a uniform, professional character. This despite the fact that Shakespeare scholars have never been more at odds about the nature of Shakespeare's own voice, how he wrote, and the kind of author he was. ${ }^{4}$ And despite the number of Shakespeare editions in print, truly experimental editions are few and far between; almost all Shakespeare editions appear within series that profess to include all the author's extant plays, and follow the same general stylistic and editorial principles. ${ }^{5}$

Indeed, Shakespeare editing is currently treated as much more science than art. Editors are expected to have a mastery of early modern English plays, literature, and culture, as well as the textual and scholarly tradition of the plays they edit, and the best editors mobilize this learning with subtlety, finesse, and brilliance. But most do not see themselves as engaged in making a beautiful edition of a play, or of making an edition that, like an audacious director, might remake the play in the minds of its readers. Are directors involved in Shakespeare editing? Are poets and active playwrights? Other than the occasional director's foreword, I know of no such meddling with the profession of Shakespeare editing. If we believe that Shakespeare's art was a collaborative one, then why do we not allow and encourage teams of creative people to present plays in radically new ways? And if we believe Shakespeare saw himself as a literary author, why do we not allow people whose qualifications are more literary in the broad sense

4. On the debate about what kind of author Shakespeare was, see ERNE and KIDNIE 2004, and their introduction to the book (1-7), as well as the forum in Shakespeare Studies 36 (2007): 19-131. In introducing their book, Erne and Kidnie come to this conclusion: "The sum of these essays suggests that whether, and if so how, we have access to authors (rather than just manuscripts and printed texts) is a question that remains wide open" (9); Patrick Cheney, in introducing the Shakespeare Studies forum, comes to much the same conclusion when, surveying the arguments of several prominent scholars on various conflicting interpretations of Shakespearean authorship-primarily theatrical or literary, individual or collaborative- "no one seems to be budging" (CHEney 2007, 20). With such a lack of consensus about the fundamental nature of the plays and their author, a greater diversity of editorial approaches seems all the more necessary.

5. The claim is a broad one, but when the question was put to a Shakespeare Association of America seminar in 2008 that included editors of both print and web editions, as well as a general editor, the consensus was that it is true; such an edition as Michael Warren's of King Lear is an exception (WARREN 1989). 
to work hand-in-hand with those whose early modern qualifications can guard against anachronism and error?

Though perhaps even anachronism and error might be tonic too. ${ }^{6}$ This essay argues as much. It began in frustration in reading As You Like It, sensing a certain dynamic at work, but unable to find a language to illuminate it. In this case, I found a way forward by happening on, in Furness's variorum edition, a comment and a suggested emendation by a not-well-reputed eighteenth-century editor of Shakespeare, William Warburton. Immersing myself in an editorial controversy that has no weight with modern editors (I call it a "dead crux" - a passage that was once emended and argued over where now the Folio reading has become unquestionable), I found myself carried into a productively distorting view of a part of the text that had never seemed problematic. Eventually, I found Warburton's distorting view to make sense as an extension of one of the mindsets in the scene-a hyper-rational vision, clashing against a mysticizing one. Warburton's shrill voice clarified for me a complex of gendered and opposed voices in this scene that radiates outward into the surrounding play. So the old, obsolete edition, with its unprofessional, grating, distorting view of the play, ends up allowing me a new purchase, a new way forward in 2012. If there were more editions as tendentious as Warburton now, that would be a good thing. We ought to allow a greater variety of voices to take the editorial stage in Shakespeare, even if we may find their work shrill, distorting, or simply wrong.

1. Before Warburton, however, I want to begin with the passage from As You Like It that he comments on, as it is presented and annotated in a modern edition, the Arden 3 by Juliet Dusinberre (2006). At the end of this essay, I will return to Dusinberre's glosses for a final model of the overall relationship of text, commentary, and meaning in my analysis, but for now they are here to provide a sense of the comfortable professionalism of modern Shakespeare editing, what some years ago, beginning a larger project on Rosalind in Spenser and Shakespeare, I found oddly oppressive. The idea now is to highlight just how far Warburton is from the interests and

6. The last decade has also seen the rise of presentism as a response to the new historicism, the complex products of which can be seen, for example, in Linda Charnes' "Anticipating Nostalgia” (Charnes 2009), and de Grazia's article on anachronism, in which she notes that historicism's mantra, "always historicize", always contained an implicit "never anachronize", something which she here brings considerable pressure against (DE GRAZIA 2010). 
sensibilities of the modern editor. Here is the passage in question, from act 1 , scene 2, where Celia, having heard of Charles the wrestler's lethal skill, urges Orlando to reconsider fighting him:

Young gentleman, your spirits are too bold for your years. You have seen cruel proof of this man's strength. If you saw yourself with your eyes or knew your self with your judgement, the fear of your adventure would counsel you to a more equal enterprise. (165-70)

About this passage, Dusinberre supplies one footnoted comment:

167 If . . . eyes It was a favourite Renaissance paradox that the eyes look outward and therefore do not see their owner; see Davies, Nosce Teipsum (1599): 'the eye, ... Whose rayes reflect not, but spread outwardly, / Not seeing it selfe, when other things it sees' (5). See TC 3.3.96-112 and Dusinberre, 'TC', 92-3.

For frequent readers of scholarly Shakespeare editions, none of this will appear strange or foreign - as indeed, for me, it was oppressively familiar-but in case a present reader lacks that familiarity, I will briefly discuss what is going on here. Dusinberre, after saying that Celia's "if you saw your self with your eyes" invokes a "favourite Renassance paradox", provides evidence for that by referencing a contemporary text by Sir John Davies. The quotation from Davies isn't really enough to support this point, but the title, if one knows some Latin, does better-Know Yourself, that is. What comes afterward is even trickier - an abbreviation that must be looked up if Troilus and Cressida isn't on the tip of one's tongue, and then a Dusinberre article, also requiring retrieval.

It might be objected that, for Celia, there is little sense of either paradox or fascination, but the comment's full significance only comes into focus with Dusinberre's later comments, which create a network of association whereby the paradox is effectively evoked by its proximity to language used elsewhere in the play. In act 3 , we come upon a scene where lack of self-knowledge, because of lack of ability to see oneself, is much more easily adduced as something that drives the action. The scene is Rosalind's interruption of Silvius's fruitless efforts to woo the shepherdess Phoebe. According to Rosalind, Phoebe does not know her own worth, particularly the degree of her beauty, for if she did, she would accept Silvius's offer of marriage, recognizing that she can do no better. The proliferation of references to "eyes" and to various situations of looking, being looked upon, and the 
power of eyes to "hurt" or "tangle" or charm, or not, is such that a reference to Renaissance fascination seems quite justified. Dusinberre waits for Rosalind to say "Know yourself" (3.5.58) to make the link: "Rosalind's command would have been familiar to educated Elizabethans from many different sources. See 55n. [on flattering self-reflection]; Davies Nosce Teipsum; and 1.2.167n" (280) — that last reference being to the earlier moment in act 1 , scene 2, with which we began.

There is nothing unusual about this comment, but unpacking it demonstrates just how much is packed in, how much of a specialized vocabulary, abbreviations, how much work pulling together references within and without the play is all contained in a single friendly footnote. There is a lot to make students and scholars alike feel accomplished, once they can decipher a footnote like this and reach the point where it feels familiar. Note also how this work is couched in historical terms: by writing about a "favourite Renaissance paradox", Dusinberre implies that As You Like It's original audience and readers would have detected the glow of significance around "see yourself . . . know yourself" that Dusinberre's comments create in this edition. So by learning the modern method of Shakespearian annotation, and by following Dusinberre's comments around As You Like $I t$, the final result is that we are closer to Shakespeare's originally intended readers and listeners — so the thinking goes.

2. And we are not quite finished with the passage in its modern presentation. Below the commentary, in Arden editions, is a smaller space, in a smaller font, for textual notes. Two such notes appear for the passage in question:

167 your] your own Rowe2; our Hanmer

and then for "your judgement"

\section{$168{ }^{1}$ your] our Hanmer}

Now the notation becomes truly challenging for the uninitiated. The introduction provides the key: "the textual notes are designed to let readers know when the edited text diverges from the early edition(s) on which it is based" (xiv). The introduction continues:

The textual notes take a form that has been in use since the nineteenth century. This comprises, first: line reference, reading adopted in the text 
and closing square bracket; then: abbreviated reference, in italic, to the earliest edition to adopt the accepted reading, italic semicolon and noteworthy alternative reading(s), each with abbreviated italic reference to its source. (xiv)

We can gather then that in the case of the two notes quoted above, we are looking purely at "noteworthy alternative reading(s)" - the lack of an italicized source of the bracketed word tells us that this word is what is in the Folio; the superscript 1 for the line 168 "your" identifies it as the first of the two in the line.

What also seems noteworthy is the extent to which this information stands passively at the bottom of the page in comparison with the nontextual comment. The abbreviations and compression make the comment challenging enough to follow, but it is hard to imagine another circumstance where one would carefully consult the textual notes except if one had a doubt about a particular word, an odd phrase, or, in a text that, unlike As You Like It, had two or more significant candidates for copy-text, to check in with what other texts did with that word. As a stream of information, it is clearly one entirely separate from the explanatory, associating, historicizing work of the commentary above. And the smaller font and position on the page likewise makes it clear what is more important than what: text first, then editorial comments, then textual apparatus.

3. In the eighteenth-century edition that I will turn to now, that hierarchy is inverted. Far from highlighting subtle networks of association in the text, William Warburton, whose comment I am using here, reads with a hairtrigger sensitivity to error and absurdity. ${ }^{7}$ In the speech by Celia I quoted above he finds a blatant error, writing that makes no sense. For Warburton, Celia must mean that Orlando should listen to her judgment, see himself with her eyes and those of Rosalind. What does she know about his judgment, which has anyway led him to the brink of this catastrophe? It is her own judgment that she is expressing, and that she is urging him to heed. Here again is the comment by Celia in the form that it came to Warburton:

7. William Warburton (1698-1779) was Bishop of Gloucester, author of several theological monographs, friend and literary executor to Alexander Pope, and editor of Shakespeare, in an eight-volume edition of 1747. Warburton's edition was followed within a year by a vicious satirical assault on its editorial practices (EDwARDs 1748). Its reputation hasn't recovered much since then. 
Young Gentleman, your spirits are too bold for your years: you have seen cruel proof of this man's strength. If you saw your self with your eyes, or knew your self with your judgment, the fear of your adventure would counsel you to a more equal enterprise. $^{8}$

And here is Warburton's full note:

If you saw your self with Y O U R eyes, or knew your self with Y O U R judgment,] Absurd! The sense requires that we should read, o U R eyes, and O U R judgment. The argument is, Your spirits are too bold, and therefore your judgment deceives you; but did you see and know your self with our more impartial judgment you would forbear. (WARBURTON 1747, 2:303) ${ }^{9}$

When I first came upon this comment I was not, to be sure, reading Warburton's own edition - I was reading Henry Howard Furness's variorum edition of 1890, readily accessible on many library shelves as well as, with a bit of looking, on Google Books. The comment struck me as bracingly strange. It seemed wrong and unnecessary, indeed, as palpably absurd as Warburton seemed to feel the unemended text to be. It seemed like a distortion within Warburton comparable to a mistake of perspective for a viewer-looking at a large unfamiliar space, for example - that can be readily and permanently corrected by either exploring the space or explaining to the viewer his mistake. And indeed, to the first editor to comment next on the same passage, Samuel Johnson, Warburton seemed to be making a big something out of nothing. Johnson's edition quotes and addresses Warburton

8. Warburton's copy-text, reproduced here, was TheOBALD 1733, 2:197. Interestingly, in his later edition of 1740, Theobald kept this passage the same, except for an added "own" before "eyes", as in "If you saw your self with your own eyes . . ". (2:274). For the record, the Folio text is the following: "Yong Gentleman, your spirits are too bold for your yeares: you haue seene cruell proofe of this mans strength, if you saw your selfe with your eies, or knew your selfe with your iudgment, the feare of your aduenture would counsel you to a more equall enterprise”. This reproduced from Hinm an 1968, TLN 336-42.

9. Warburton's emendation was first made by Thomas HANMER in his six-volume edition of 1743-44, but Warburton does not acknowledge this; this explains why Hanmer is cited in Dusinberre's textual note, and not Warburton. The full title of Warburton's edition is worth quoting for its confidence and ambition: The Genuine Text (collated with all former Editions, and then corrected and emended) is here settled: Being restored from the Blunders of the first Editors, and the Interpolations of the two Last... 
directly: "I cannot find the absurdity of the present reading". He continues, "If you were not blinded and intoxicated" - and momentarily we wonder: accusations leveled at Warburton? But no- "blinded and intoxicated says the princess, with the spirit of enterprise, if you could use your own eyes to see [sic], or your own judgment to know yourself, the fear of your adventure would counsel you" (Johnson 1765, 2:16). ${ }^{10}$ "Your own eyes" and "your own judgment" says his revoicing of Celia, the "own"s making it abundantly clear that it is Orlando's sight and judgment she is speaking of.

Though Samuel Johnson was much less overtly hostile than Warburton's satirist, Thomas Edwards, this example does fit squarely with the assessment of Warburton's editing that Johnson makes in the introduction to his edition:

The original and predominant error of his commentary is an acquiescence in his first thoughts; that precipitation which is produced by consciousness of quick discernment; and that confidence which presumes to do, by surveying the surface, what labor only can perform, by penetrating the bottom. His notes exhibit sometimes perverse interpretations, and sometimes improbable conjectures; he at one time gives the author more profundity of meaning, than the sentence admits, and at another discovers absurdities, where the sense is plain to every other reader. (1:liii)

This seems to sum up the situation with the Celia comment as clearly as anyone might need. And yet, returning to Furness, one sees that in spite of Johnson's clear-headedness, editors and commentators continued to debate Warburton's proposition for a hundred years after he made it. This is what I am calling a "dead crux", in the sense that no one is debating Warburton's suggested emendation any more, and since Warburton wasn't the first editor to suggest it, he doesn't even appear in the fine print of the Arden3 textual apparatus we examined above. But I also see it as fascinating and rather miraculous - that this editor was able to propagate over a century a reading which even shortly after he had made it was already deemed absurd. To me, it is a fascinatingly paradoxical phenomenon to be placed next to Dusinberre's Renaissance fascination with the paradox of self-vision and self-knowledge, a phenomenon charted across editions, diachronically, in contrast with the dual-synchronic network of Dusinberre: one within As You Like It, and also across contemporary texts by Shakespeare and others.

10. Johnson reproduces Warburton's comment in full before his response. 
4. But to get to how Warburton's dead crux allowed me to break a logjam in my own thinking about As You Like It, I have to go through one more step, and the critic that inspired me to consider the border between characters' voices and the voices of commentators as more porous than it usually appears. That critic is Lawrence Lipking, in an essay called "The Marginal Gloss", published in 1979. The essay distinguishes between two broad types of printed commentary in the history of the edited text: the marginal gloss, and marginalia. As it turns out, history of the book scholarship, which has flowered in the years since 1979, has effectively negated using "marginalia" in the way Lipking suggests it be used, but the distinction is still an interesting one. Lipking writes of two fundamental genres of explanatory commentary, or "frame[s] of mind" (612), as having entirely different intentions relative to the text they frame. Older, in terms of printed editions, is the marginal gloss: "however dense the text, the gloss holds out the hope that all perplexities can be explained and all obliquities reduced to order" (613). This includes both local knots of meaning and the relationship of parts to the whole, which marginal glosses affirm, either by directing us to other places in the text, or by creating a logical sequence through a series of subheadings. Marginalia are altogether different: Lipking believes that Poe was the first to publish his own, and suggests that they would not have been published without the Romantic encouragement of "a taste for fragments and impulses, the suggestive part, rather than the whole" - the term itself is Coleridge's coinage (612). ${ }^{11}$ Rather than orienting, marginalia seeks disorientation, "offers the reader a kind of puzzle . . . a fragmentary clue to buried possibilities of meaning ... the more outrageous the clue, the better the puzzle" - and by "deciphering the apparent nonsense of the marginalia, we perform the act of reading" (609).

If we review the two comments examined in this essay so far, Lipking's distinction can both clarify their differences and further complicate matters. At first glance, Warburton would seem to be a glossator par excellence, completely focused on explaining and illuminating the text. But as Johnson points out, Warburton's readiness simply to rewrite Shakespeare's text when he finds even a hint of obscurity ends up creating more confusion and obscurity than was there in the first place - so he ends up looking more like weird marginalia in this history of Shakespeare editing than the clarifying presence he envisioned for himself. And likewise, Dusinberre might at first look like a writer of marginalia, offering with her Nosce Teipsum note "a fragmentary clue to buried possibilities of meaning". But sufficiently

11. This history is confirmed in JACKsON 2001, 7. 
decoded, we can see how she almost certainly sees herself as a glossator, clarifying the historical weight of "know thyself" for Elizabethans, as well as alerting readers to a network of considerations of this idea within the play. So Lipking's distinction is interesting but slippery.

Things reach the apex of productive slipperiness when Lipking turns to James Joyce, specifically the Storiella as She Is Syung portion of the "Night Lessons" chapter of Joyce's Finnegans Wake. Here a reader finds a central text surrounded on two sides by child glossators, and footnoted by a third below. On one side, writing hyper-scholarly glosses, is Shaun, — "HE CAN explain it all. Consistently Relevant, his comments demonSTRATE THAT HE UNDERSTANDS THE TEXT MUCH BETTER THAN IT KNOWS ITSELF" (633). On the other side is Shem, writing not explanatory glosses but poetic and playful marginalia. At the bottom of the page is Issy, for whom the text is all about the sex. And Lipking suggests the following: "The relation of text to footnote, Joyce notes, is basically chauvinistic; the wisdom of the earthdaughter looks up to the power of the übermench" (634, footnote, of course). As the episode goes on, these relations begin to break down, until

As Storiella nears its close, light dies before its uncreating word; the page literally begins to disintegrate before our eyes.

$[\ldots]$

Suddenly the scholarly apparatus has disappeared - no gloss, no marginalia, no notes. Or rather, no text. For now the text belongs to the children; they have come in from the margins, and collaborated on a letter of their own; now they mean too. (636-37)

Lipking reads in Joyce a time-lapse film of editions and editorial approaches flourishing, decaying, changing, the way we might start to see things if we could free ourselves from our temporal situatedness, from our scholarly and editorial habits of mind. Joyce, as Lipking reads him, sees "main text" and various approaches to commenting upon it as elements with their own characters, genders, relative positions of power, engaged in struggle and flux that can supersede editorial principles and intentions. This is to say, Storiella presents an allegory of textual dynamics that reveals the potential for metamorphosis and historical change on the edited page. It suggests the extent to which roles might change: serious scholarship slips into parody; poetic and provocative becomes merely perplexing; editors and authors switch positions or their roles become indistinguishably mixed. And this, 
at last, sets all the groundwork for the way Warburton started to make sense of things to me.

5. In her pathbreaking study, Shakespeare and the Nature of Women (1975), Juliet Dusinberre argued that Rosalind, in comparison with other Shakespearean heroines, is often emphatically feminine: she is "all vivacity, spirit, speed, susceptibility and fancy" (251). The reason Dusinberre posits for this concerns theatrical illusion: in order for Rosalind to work as Ganymede for great stretches of the play, and as a boy actor playing Rosalind-playingGanymede-playing-Rosalind, she must be written in sufficiently feminine fashion for the illusion to hold. With male actors and limited resources of disguise, she argues, the language had to be able to carry a sense of gender (252). Analysis of As You Like It has usually focused on genre, on the play's treatment of pastoral convention. In the broad discussion of Shakespeare's comedies and their treatment of gender, the new historicism found that As You Like It, like other comedies, ended up containing through the patriarchal structure of marriage whatever social and erotic energies it unleashed. ${ }^{12}$ Dusinberre's argument for a feminist Shakespeare, as in a Shakespeare that breaks with the prejudices of the time and considers both sexes potential equals, has not lately been in favor. ${ }^{13}$

With Warburton's comment as marginal provocation, I would like to introduce a different way of ordering the elements of the play that are in tension. At least as important as its loosening and reshuffling of gender roles is its exploration of pastoral convention which, many critics have observed, is continually in this play subject to "critical wit" (Alpers 1996, 131). Frequently that critical wit, which can also be stolid rationalism or even-tempered calculation, appears in the play in opposition to a more fanciful frame of mind. Many critics see a similar tension in pastoral itself, between the fantasy of a "golden" or prelapsarian world and the fallen present, or between "harder" and "softer" views within pastoral. These opposing points of view can be mapped right onto the "country and the city", or rather, to keep the positioning consistent, the city and the country, and thence into materialism and idealism. ${ }^{14}$ They can be mapped onto gen-

12. E.g., "if As You Like It is a vehicle for Rosalind's exuberance, it is also a structure for her containment" (Montrose 1981, 52).

13. For a history of the disillusionment with Shakespeare as a vehicle for feminism, see RACKin 2009, 49-60, esp. 54.

14. See Williams 1973. Alan Sinfield, following Williams, and arguing for the "unfinished business" of cultural materialism, finds Alpers giving in to idealism 
ders too, as in the feminine qualities of "susceptibility" and "fancy" that Dusinberre sees in Rosalind. But in this early moment in the play, when we are still in the demesne of the usurping, tyrannical duke, there is a curious precursor to the appropriations and reversals of gender positions, social positions, idealizing and skeptical casts of thought, that will become so prominent once the characters have retired or fled to Arden.

Paul Alpers argues that the skeptical voices in As You Like It, so expanded and deepened by Shakespeare relative to his source in Lodge's Rosalynde, do not finally demolish what is appealing about pastoral as it appears here (Alpers 1996, 132-34). ${ }^{15}$ The moment around Celia's speech, with Warburton's help, can be seen as an early example of how this might go, how a skeptical point of view might run into its match, and this happens through a reversal of gendered speech that presages the reversals that are to come. William Warburton in his protestations of absurdity sounds like a recognizable, recognizably male voice of dogged rationalism, none too witty, in this case-more Duke Frederick than Jaques. As Warburton declares the Folio version of Celia's speech to be absurd, other aspects of the scene ironically undermine him: Celia, however she deploys her pronouns, is wrong about Orlando, but then, it isn't clear whether Celia and Rosalind's initial address to Orlando matters semantically much at all - the point is to get to talk to him and to inspect him more closely, and as will become clear momentarily, their evaluation is as much erotic as sporting, potentially marital as martial.

To their skeptical and rational view that cuts rapidly to the sense of things, Orlando returns a mysticizing speech, all the more striking since up until this point in the play, and from his first moments on stage, he has been all about piercing the habitual acceptance of his unjust circumstances and appealing rationally for what is rightfully his. There is nothing of that Orlando in his answer: he does not answer the judgment of the women on

despite what seems to me extraordinary critical self-consciousness. Sinfield finds the whole enterprise of "literary history" to be deeply misguided (Sinfield 2006, 31-39).

15. In brief, Shakespeare's major additions and changes to Thomas Lodge's Rosalynde include the following: Jaques and Touchstone are innovations, and greatly expand the satirical material in the story, while the skeptical, searing, and satiric qualities of Rosalind vastly expand on a few hints in Rosalynde's reproaches to Montanus. At the same time the mystical and magical elements of the story are heightened - most prominently in the treatment of the transformation of Oliver and his subsequent love affair with Celia. For a modern edition of Lodge, see KnOwles 1977, 382-475. 
its terms ("Actually I've had a lot of experience wrestling farm hands that my brother forces me to cavort with — I'm really pretty good — you'll see!"), but on entirely different terms. In Dusinberre's version, we read:

I beseech you, punish me not with your hard thoughts, wherein I confess me much guilty to deny so fair and excellent ladies anything. But let your fair eyes and gentle wishes go with me to my trial, wherein if I be foiled there is but one shamed that was never gracious, if killed, but one dead that is willing to be so. I shall do my friends no wrong, for I have none to lament me; the world no injury, for in it I have nothing. Only in the world I fill up a place which may be better supplied when I have made it empty. (175-84)

Orlando has no use for their "hard thoughts", or for their prudent and reasoned assessment of his chances against the duke's champion, or his chances of getting away with his reputation untarnished. Rather he wants their unskeptical and "fair eyes and gentle wishes" as he takes on a "trial" the existential and world-altering quality of which his rhetoric emphasizes and expands even as it is palpably loose with the facts (see what Oliver says about him at the end of the previous scene for confirmation of how far he exaggerates here). Nonetheless, the speech is highly effective: before it, the prudence and skepticism of the cousins dissolve and they give him the feminine encouragement he has requested. If we see the scene as a clash between these two points of view, between rational analysis and that which dissolves and upends it, Warburton and even Johnson begin to look like comic extensions of the rational view. One toys with the notion of Warburton interceding in the scene, urging Celia to step aside while he clarifies what she means to say (and if he'd been allowed to say this, perhaps the silly young man would have listened). This extension, this carrying a thread of thinking to a comic breaking point, is something that the play does more and more as it develops, and the extension and intensification of critical reasoning takes place most spectacularly in the jubilantly masculine version of Rosalind. ${ }^{16}$

Editors and commentators do not like to consider themselves as actors or characters in the scene of the fictions they edit. This is a fundamental category error: Shakespeare is not Joyce, is not Pope with his Scrib-

16. I explore Rosalind, Shakespeare's as well as Spenser's and Lodge's, at much greater length in a book manuscript in progress, entitled What Rosalind Likes: Elizabethan Poetic Evaluation. 
lerus, is not even Johnson with his marginalia or Spenser with the possibly self-fabricated E.K. There is a bright line between what editors say about Shakespeare and what Shakespeare, however complicatedly and spread across however many contradictory folios and quartos, says. And yet this moment in As You Like It seems one where the dynamics of the scene in question anticipate, provoke, and thus partially envelop the commentary that surrounds it. And this goes both ways: by voicing a more extreme, hyper-rational version of the voice of one character, Warburton highlights the play's own interest in taking this point of view to extremes. His distortion of the text anticipates the distortion, indeed, the violence that will be on display when Rosalind takes this as far as it can be taken, as she reads the love letter from the unfortunate Phoebe in act 4, scene 3.

6. For a last consideration of the relationship of text and commentary, I want to follow Dusinberre's gestures toward Troilus and Cressida, just after the reference to self-knowledge that she cites. In this scene, Ulysses is laying a trap for Achilles, and after an allusion to the paradox of self-seeing that is rebuffed by Achilles as a boring commonplace, Ulysses accordingly raises his game:

I do not strain at the position-

It is familiar - but at the author's drift,

Who in his circumstance expressly proves

That no man is the lord of anything,

Though in and of him there be much consisting,

Till he communicate his parts to others;

Nor doth he of himself know them for aught

Till he behold them formed in th'applause

Where they're extended — who, like an arch, reverb'rate

The voice again, or, like a gate of steel

Fronting the sun, receives and renders back

His figure and his heat. I was much rapt in this,

And apprehended here immediately

Th'unknown Ajax. (3.3.113-26 in Bevington 1998)

The two metaphors Ulysses gives in quick succession take on more significance in light of the argument of this essay: the "arch" that reverberates the voice, and "the gate of steel" that "receives and renders back" the image and heat of the sun. Lipking's survey of the history of glossing and marginalia tends to make one alert to the shifting relationships of gloss and text, and 
to the fact that they sometimes together demand holistic aesthetic analysis - this was certainly the case with Coleridge, who wrote his own glosses, or Joyce in Finnegans Wake, and various other postmodern texts where the margins are grabbed up and put to use before an editor ever arrives on the scene. The notes and glosses in a Shakespeare edition - Johnson, Furness, Dusinberre - can be seen as exactly the sort of reflective, rerendering surfaces Ulysses describes. By "receiving and rendering back" they set off waves of association, amplifying, as Lipking describes it, "wayward . . . traces" that "spring up spontaneously around a text unaware of their presence" (612). We can go as far as Ulysses, if we like, and suggest that Shakespeare is indeed nothing without such echoic, reflective structures; we can say that all the power of the text is in reflection; but we can also say that all the power is in the sun, and in the voice, and that reflection merely subserviently propagates what would find other media for propagation in its absence.

But Ulysses' point, for Shakespeare editing, remains for me both irrefutable and little-acknowledged. Shakespeare editions powerfully shape the plays they edit, suggest the tone of their speeches, scenes, arguments, mediate our sense of their complexity, obscurity, and clarity. Shakespeare editors whether they like it or not extend and mediate the plays; their voices take a place in an ever-expanding echo-chamber of voices that move within and without the loose borders of "Shakespeare's text". No matter how professional, how consistent, and how much based in sound, rational principles, editors participate aesthetically in the plays they edit. To my mind, we would all be better off if there were wider acceptance of this, as well as a greater commitment to the possibilities it implies. We would also be better off if more editors and more publishers accepted as a duty not just the providing of clarifying, making-it-easier editions, as well as scholarly, makingus-feel-smart editions, but also genuinely experimental, making-it-strange editions, as is so often the case in Shakespearean productions. Directors know that they have to get audiences to see and listen to well-known plays afresh, in order for the plays to have the impact they can and should have, in order for them to matter as living works of art. This doesn't seem to be an editorial principle anywhere that I can find. It should be.

Purdue University North Central 


\section{Works Cited}

Alpers, Paul. 1996. What Is Pastoral? Chicago: University of Chicago Press.

$\mathrm{BACH}$, Rebecca Ann. 2007. Shakespeare and Renaissance Literature before Heterosexuality. New York: Palgrave Macmillan.

Bevington, David, ed. 1998. Troilus and Cressida. London: Arden Shakespeare.

Charnes, Linda. 2009. Anticipating Nostalgia: Finding Temporal Logic in a Textual Anomaly. Textual Cultures: Texts, Contexts, Interpretation 4 (1):72-83.

Cheney, Patrick. 2007. "Introduction”. Shakespeare Studies 36:19-25.

De Grazia, Margreta. 1991. Shakespeare Verbatim: The Reproduction of Authority and the 1790 Apparatus. Oxford: Clarendon Press.

2010. Anachronism. In Cultural Reformations: Medieval and Renaissance in Literary History, edited by Brian Cummings and James Simpson, 13-32. Oxford: Oxford University Press.

DusinberRe, Juliet. 1975. Shakespeare and the Nature of Women. London: MacMillan. —, ed. 2006. As You Like It. London: Arden Shakespeare.

Edwards, Thomas. 1748. A supplement to Mr. Warburton's edition of Shakespear. Being the Canons of criticism, and glossary, collected from the notes in that celebrated work, and proper to be bound up with it. London.

ERne, Lukas. 2008. Shakespeare's Modern Collaborators. London: Continuum.

Erne, Lukas, and Margaret Jane Kidnie, eds. 2004. Textual Performances: The Modern Reproduction of Shakespeare's Drama. Cambridge: Cambridge University Press.

Evans, A. W. 1932. Warburton and the Warburtonians: A Study in Some EighteenthCentury Controversies. London: Oxford University Press.

Furness, H. H., ed. 1890. As You Like It. Philadelphia: J. B. Lippincott.

Grafton, Anthony. 1997. The Footnote: A Curious history. Cambridge, Massachusetts: Harvard University Press.

Hanmer, Thomas. 1743-44. The Works of Mr. William Shakespeare ..., 6 vols. London.

Hinm an, Charlton, ed. 1968. The First Folio of Shakespeare. New York: W. W. Norton.

Jackson, H. J. 2001. Marginalia: Readers Writing in Books. New Haven: Yale University Press.

- 2005. Romantic Readers: The Evidence of Marginalia. New Haven: Yale University Press.

Johnson, Samuel, ed. 1765. The Plays of William Shakespeare .. ., 8 vols. London.

KING, John N., ed. 2010. Tudor Books and Readers: Materiality and the Construction of Meaning. Cambridge: Cambridge University Press.

Kinney, Arthur. 2004. Shakespeare's Webs: Networks of Meaning in Renaissance Drama. New York: Routledge.

Knowles, Richard, ed. 1977. A New Variorum Edition of Shakespeare: As You Like It. New York: The Modern Language Association of America.

Lipking, Lawrence. 1977. The Marginal Gloss. Critical Inquiry 3 (4):609-55. 
Marcus, Leah S. 1996. Unediting the Renaissance: Shakespeare, Marlowe, Milton. New York: Routledge.

2007. "Editing Shakespeare in a Postmodern Age". In A Concise Companion to Shakespeare and the Text, edited by Andrew Murphy, 128-44. Oxford: Blackwell.

Montrose, Louis Adrian. 1981. “The Place of a Brother' in As You Like It: Social Process and Comic Form". Shakespeare Quarterly 32:28-54.

Murphy, Andrew. 2003. Shakespeare in Print: A History and Chronology of Shakespeare Publishing. Cambridge: Cambridge University Press.

2007. "The Birth of the Editor". In A Concise Companion to Shakespeare and the Text, edited by Andrew Mur phy, 93-108. Oxford: Blackwell.

Rackin, Phyllis. 2009. "Dated and Outdated: The Present Tense of Feminist Shakespeare Criticism". In Presentism, Gender, and Sexuality in Shakespeare, edited by Evelyn Gajowski. New York: Palgrave Macmillan.

Sherman, William H. 2008. Used Books: Marking Readers in Renaissance England. Philadelphia: University of Pennsylvania Press.

Sinfield, Alan. 2006. Shakespeare, Authority, Sexuality: Unfinished Business in Cultural Materialism. London and New York: Routledge.

Theobald, Lewis, ed. 1733. The Works of Shakespeare, in Seven Volumes . . . London. 1740. The Works of Shakespeare: in Eight Volumes . . . London.

Warburton, William ed. 1747. The Works of Shakespear in Eight Volumes ... London. Warren, Michael, ed. 1989. The Complete King Lear, 1608-1623. Berkeley: University of California Press.

Williams, Raymond. 1973. The Country and the City. New York: Oxford University Press. 